\title{
EVALUATION OF PRIMARY STABILITY IN IMMEDIATE NON SUBMERGED ROOT ANALOGUE ZIRCONIUM IMPLANTS: A PRELIMINARY STUDY
}

\author{
Haytham A. Elkhouly*; Nader Elbokle ${ }^{* *}$ and Mohammed Khashaba ***
}

\begin{abstract}
Objective: The aim of the present study was to evaluate the primary stability of immediate, custom made zirconium root analogue implant. Our secondary outcome was to evaluate Marginal bone changes at the day of the implantation, and after 3 months.

Patients and methods: This study included 8 immediate implant placements in fresh sockets in esthetic zones using custom made zirconium implants. A Pre-operative CBCT using NewTom-Giano machine (Giona Cefla s.c). was obtained for each patient to get the measurements $\&$ dimensions of the un-restorable teeth. Patients were prepped for the procedure under local anesthesia. Atraumatic extraction of the teeth with curettage of the extraction socket was done. The extracted remaining roots were disinfected then mounted on the Identica-Hybrid laser scanner to produce an stl. file of the remaining roots. Then using the "Ceramill" CAD software (Amann Girrbach AG, Herrschaftswiesen, Koblach) to modify the root analogue by adding macro retentive "blebs" on the lateral surfaces of the custom made zirconium implant. Transferring the design to the milling machine (Roland DWX-51D) using "Superfect Zir" and "rainbow "TM" zirconium blocks. The implants were subjected to surface treatment using sand blasting method, and then sterilized to prepare for implantation. Patients were recalled after 3 days for insertion; and implantation using tapping technique, to achieve primary stability. The primary stability was measured using the periotest $\mathrm{M}$ device as a primary outcome. Standardized paralleling technique was used to assure the seating of the implant inside the socket after insertion, \& for evaluation of the marginal bone changes as a secondary outcome.
\end{abstract}

Results: all custome made zirconium implants failled to osseointegrate

Conclusion: Within the limitations of this study, the authors could not measure the stability nor the marginal bone changes of custom made zirconium implants.

KEYWORDS: custom-made zirconium dental implants, primary implant stability.

* Assistant Lecturer at MSA University Oral \& Maxillofacial Surgery Department

** Head of Faculty of Dentistry Educational Hospital, Cairo University, Alkasr Alainy, Head of MSA university Oral \& Maxillofacial Surgery Department

** Lecturer of Oral \& Maxillofacial Surgery, Cairo University - Alkasr Alainy 


\section{INTRODUCTION}

Brånemark described the Osseointegration process more than 50 years ago, together with his team started a new era of dental implants. Their work inaugurated the research on different designs, shapes and materials of dental implants ${ }^{(1,2)}$.

The history of dental implants goes back thousands of years ago to the ancient times of the Egyptian civilization 3000 B.C. Yet the concept of replicating the teeth with custom-made root analog implants is not new for the dental world. The concept of Osseointegration first appeared in 1950 Europe by Brånemark stated that titanium implants that are biocompatible can be integrated with alveolar bone changed everything ${ }^{(1)}$.

A replica of a tooth implant was reported as early as 1969; but the polymethacrylate auto polymerized and heat processed replica, used to fabric the tooth was encapsulated by soft tissue rather than being osseointegrated $^{(3)}$.

Stability is a significant factor in evaluating the success of the dental implant. It is considered an implant failure if mobility is detected after implantation ${ }^{(4)}$.

Esthetics is the focus of millions of people around the globe; making the choice of having a white aesthetic teeth a plausible choice for the patients of all ages. The boom of social networking we see nowadays and the technological advancements in high definition cameras made taking a good photograph with a shiny white celebrity like perfect smile a necessity ${ }^{(5)}$.

Zirconium implants is introduced to overcome the poor esthetic of titanium implants in anterior teeth. Metal display of titanium subgingivally in a perfectly osseointegrated implant is considered a failure by the patients due to poor esthetics. Zirconium implants is the answer for this dilemma for its tooth colour resemblance; its good mechanical properties, high flexural strength, hardness, and capability of withstanding long-term loading ${ }^{(6)}$.
The integration of digital technology in today's Maxillofacial Surgery by using the CAD/CAM, laser and intraoral scanners proved through the years enhanced treatment outcome, by producing a custom made alternative similar to the natural $\operatorname{parts}^{(7)}$.

Immediate placement proved success in terms of atraumatic procedure, faster healing, less time consuming and low cost to the patient \& operator as well ${ }^{(8)}$.

\section{PATIENTS AND METHOD}

This study included 8 immediate implant placements in fresh sockets in esthetic zones using custom made zirconium implants. Patients were selected randomly from outpatient clinic of Oral and Maxillofacial Surgery Department, Faculty of Dentistry, Cairo University according to the following criteria:

\section{Eligibility criteria}

1. Patients in good health (American Society of Anesthesiologists ASA Class I).

2. Age range is between 18 and 60 years old.

3. Patients with non-restorable anterior tooth in need for an implant.

4. Absence of any local disease at implant site.

5. Patients with sufficient bone level for implant placement, with marginal bone loss $\leq 3 \mathrm{~mm}$.

6. Patients with good oral hygiene.

\section{Exclusion criteria:}

1. Patients having active sites of pathosis in the implant area.

2. Patient with sever gingival recession.

3. Patients with systemic condition

4. Patients on long term steroid therapy.

5. Patients on immunosuppressive drugs with increased liability of infection. 
6. Patients using chemo-therapeutic agents.

7. Patients with bleeding disorders.

8. Patients with para-functional habits.

9. Patients who are heavy smokers.

10. Patients with psychiatric disorders.

11. Pregnant females, due to the effect of pregnancy on the periodontal statue of the patient.

All the patients were given the necessary information about the procedure including its prognosis, potential complications and they gave their approval to participate in a written informed consent.

\section{Preoperative phase}

Detailed preoperative data were collected from all patients it including name, age, gender, occupation, address, past and present medical history and dental history.

Clinical examination was done including inspection of oral and para oral tissues in addition to evaluation of the intermaxillary space.

Preoperative cone beam computerized tomography was performed to evaluate bone volume and density.

\section{Surgical procedure and intraoperative evaluation}

\section{A) Patient Preparation phase}

- Patients were prepared according to oral surgical standards, they were scrubbed, draped and the site was cleaned using $1 \%$ Betadine* solution.

- The patients were asked to use the povidone iodine solution to rinse thoroughly before the procedure.

The procedure was performed under local anesthesia (infiltration technique) using Septocaine ${ }^{*} * *$. Anesthesia was administered to the patient a few minutes before surgery.
- The extraction of the remaining root was done atraumatically using periotomes with minimal expansion of bone around the root.

- A forceps was then used to apically grip the remaining root and in a rotatory movement extracting the remaining root without violating the labial or palatal surfaces of the socket, leaving it intact.

- Curettage of the extracted socket using a spoon curette; and followed by irrigation of the socket using saline $(\mathrm{NaCl} 0.9 \%)$ solution to clear the socket from any granulation tissue or periodontal ligaments remaining after the extraction.

- The patient was instructed to bite on a piece of gauze for an hour after extraction. And was instructed to avoid touching the extraction site with his fingers or tongue repeatedly.

\section{B) Implant preparation phase}

- The extracted remaining root was rinsed and then transferred to the laboratory after disinfecting with an alcoholic solution.

- Desktop laser scanner (Identica-Hybrid)** was used to scan the extracted root, producing an stl. file of the tooth (Figure. 2). Then (Ceramill)* CAD software was used to design the abutment and add the root macro-retention (blebs) to the root analogue. (Figure. 1)

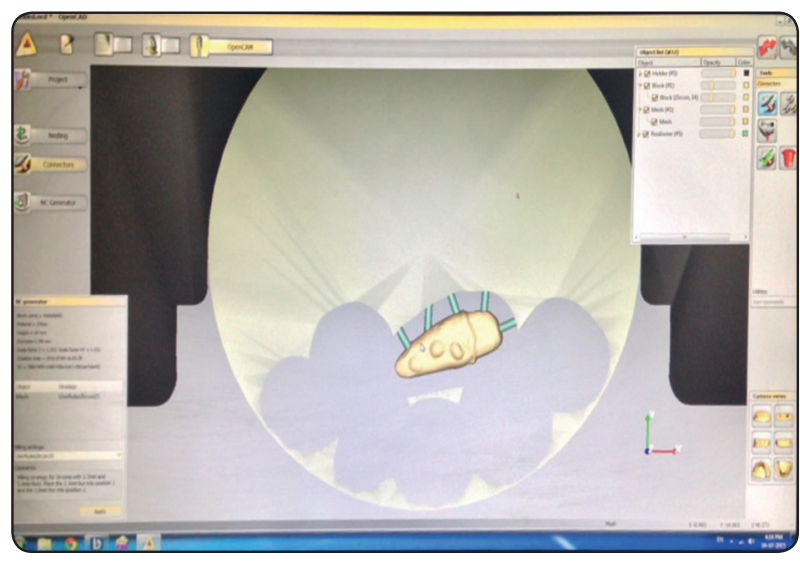

Fig. (1) Preparing the custom-made zirconium implant for milling on the CAD software 
- The design was transferred then to the milling machine (Roland DWX-51D).

- The zirconium implants were subjected to surface treatment using sand blasting machine under 1.5 bar employing $110 \mu \mathrm{m}$ abrasive alumina particles; to act as a retentive mechanism during the initial implantation phase. (Figure 3).

- The custom made implants were sterilized by steam autoclave.(Figure 4)

\section{C) Implant insertion:}

- The patient was recalled after 3 days for implant insertion.

- Supraperiosteal injection (local infiltration) anesthesia of the implant site.

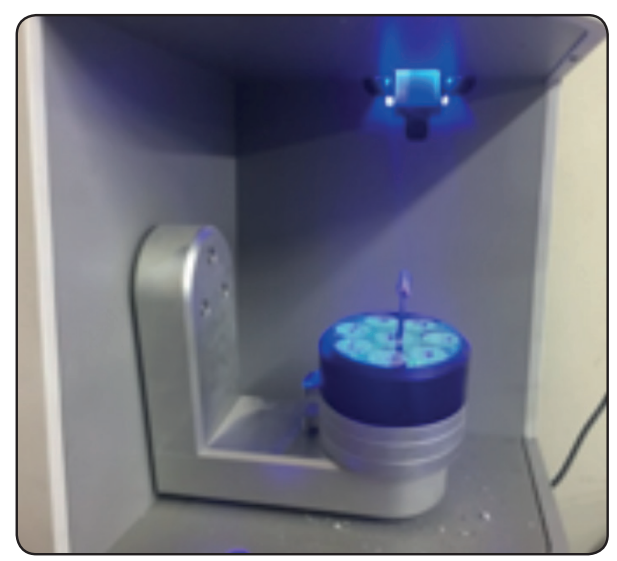

Fig. (2) Laser scanning

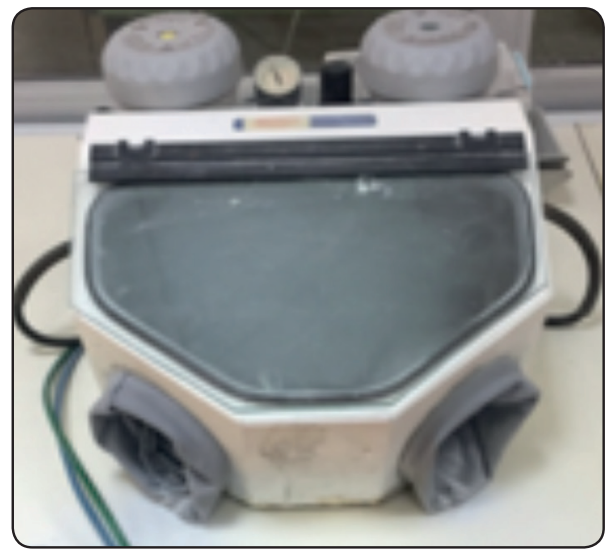

Fig. (3) Sand-blasting machine
- Curettage and disinfection of the socket in preparation prior to implant insertion.

- Insertion of the custom made zirconium implant in the empty socket was done using tapping technique, with a mallet to achieve primary stability. (Figure 5).

- The custom made zirconium implant was radiographed using paralleling technique to make sure it was seated inside the socket properly.

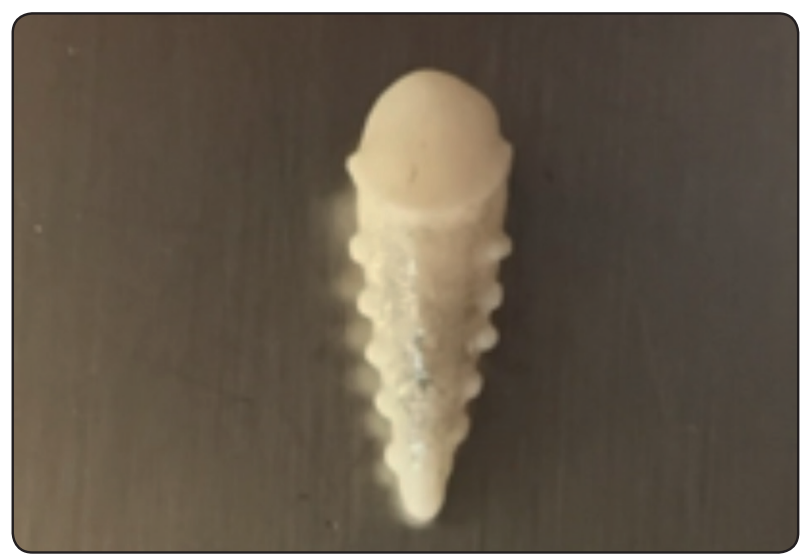

Fig. (4) Custom made zirconium implant

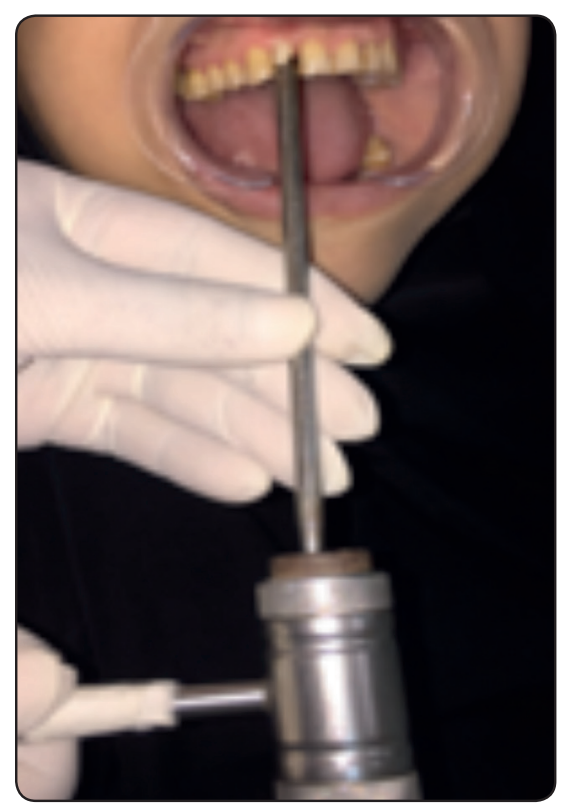

Fig. (5) Tapping technique 


\section{D) Primary stability Measurement}

The periotest $M^{*}$ was used to measure the implant stability. The periotest was positioned at the center of the tooth and on the horizontal axis of the implant. The distance of the device from the implant is approximately $0.6-2 \mathrm{~mm}$. The device produce 16 beats or impacts in 4 seconds to the object (implant), so maintaining the Periotest in its position for at least 4 seconds is a must. Two readings were collected to measure and indicate the implant mobility. There is 10 - 20 minutes time difference between the 2 readings, to allow the return of the alveolar ridge into its normal state

\section{Meaning of the Periotest values:}

Generally the Periotest scale ranges from -8.0 to +50.0. The smaller the Periotest value, the higher the stability / damping degree of the implant.

$\begin{array}{cc}\text { Clinical degree of tooth loosening } & \text { Periotest M value } \\ \text { 0 } & -8.0 \text { to }+9.9 \\ \text { I } & 10.0 \text { to }+19.9 \\ \text { II } & 20.0 \text { to }+29.9 \\ \text { III } & 30.0 \text { to }+50.0\end{array}$

\begin{tabular}{|c|l|}
\hline Periotest value range & Interpretation \\
\hline-8.0 to 0.0 & $\begin{array}{l}\text { Good osseointegration; the } \\
\text { implant can be loaded }\end{array}$ \\
\hline+0.1 to +9.9 & $\begin{array}{l}\text { Clinical examination is required; } \\
\text { loading of the implant might or } \\
\text { might not be possible, depending } \\
\text { on implant type and clinical } \\
\text { situation }\end{array}$ \\
\hline+10.0 or higher & $\begin{array}{l}\text { Osseointegration is insufficient, } \\
\text { the implant cannot be loaded }\end{array}$ \\
\hline
\end{tabular}

\section{Sitting position of the patient:}

- The recommended position by the manufacturer is an upright postion with a corresponding vertical position of the implant.

- The upper and lower jaw should not have any contact with each other. The patient also shouldn't open too wide, only enough for an easy access for the device to take the reading.

\section{Point of application at the implant surface}

- Position the periotest $\mathrm{M}$ from the vestibular surface (buccally or labially)

- The manufacturer advised to measure the one piece implants at the upper end of the implant. (Fig. 6)

- The Periotest M must be held in a horizontal position; a slight bend upward or downward (up to $+/-25^{\circ}$ ) will be accepted.

- The distance between the tip of the probe and the tooth which is valid is between 0.6 and 2.5 millimeters. If the device is held more closely than $0.6 \mathrm{~mm}$ or further away than 2.5 , there will

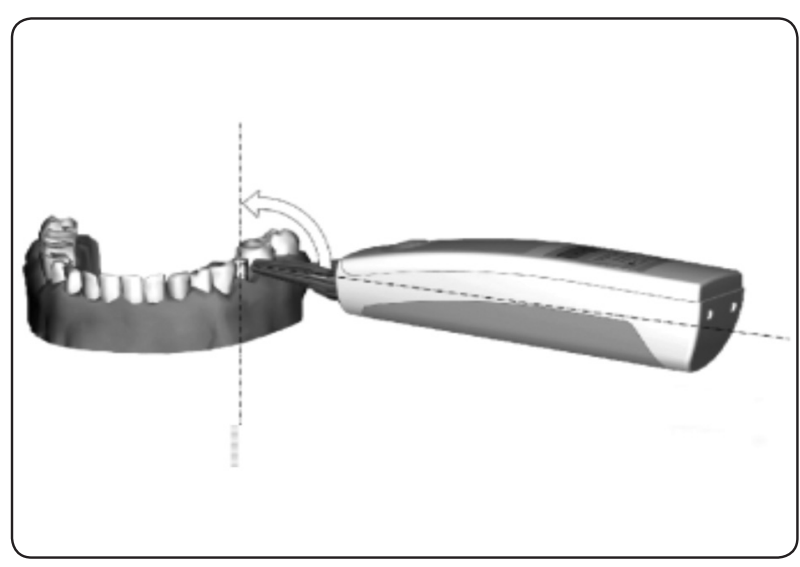

Fig. (6) Horizontal Posture of periotest M taking the readings

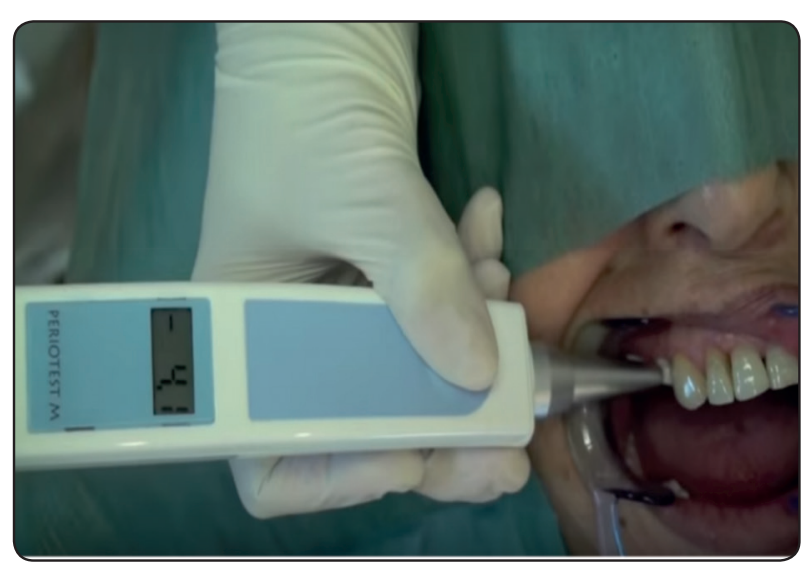

Fig. (7) Measuring the primary stability of the custom made implant using the Periotest $\mathrm{M}$ 
be no valid reading. The manufacturer advised to make multiple tests for the measurements as a demo for the procedure before starting to take the actual final readings.

- The measuring cycle consists of 16 impulses of the pressure sensitive tapping head against the implant. The device emits a low tone with each impulse. If the distance of the device is farther than $2.5 \mathrm{~mm}$ from the implant and the impulses are invalid the periotest $\mathrm{M}$ emits a high tone to alert the operator, to correct the device position and posture during the measurement process. The cycle takes approximately 4 seconds, with a short melody playing at the end of it. At least 4 impulses must be valid; if less no readings will be indicated on the screen display.(Figure 7)

- All readings were taken by the same operator conducting the study .

- A radiographic $\mathrm{x}$-ray was taken using a paralleling technique by the aid of a paralleling device. (Figure 8)

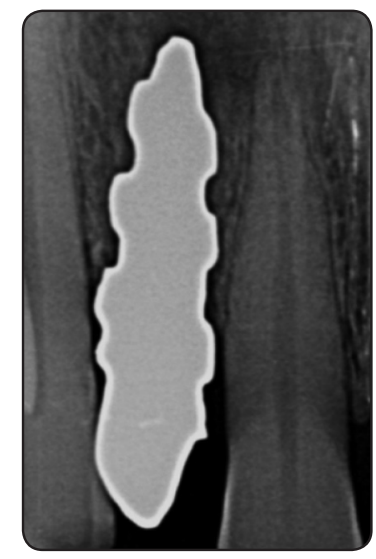

Fig. (8) Standardized parallel radiograph

\section{E) Evaluation:}

\section{i. Clinical evaluation:}

Implant success was evaluated at the time of insertion and after a month through the following criteria:
- Implant is immobile when clinically tested;

- No persistent pain or infection related to the implant.

- The implant design does not hinder placement of a crown or prosthesis with an appearance that is satisfactory to the patient and dentist. Since the implant was one piece a finish line was constructed on the implant surface using the CAD software for an easy loading of the prosethesis.

\section{ii. Radiographic evaluation:}

No evidence of peri-implant radiolucency was present on the peri-apical radiographic examination.

\section{F) Outcomes:}

\section{Primary outcome: Periotest evaluation}

- Using a periotest device, measure the primary stability of the implant at the time of implantation and after 3 months. The patient was seated that the jaw tested is horizontally aligned with the floor. Rxsstering the same values 2 consecutive times.

\section{Secondary outcome: Marginal bone changes eval-} uation:

- Intraoral radiograph using a standardized digital parallel technique was taken first at day of implantation. Using a paralleling device with aiming rings, indicator arms and a rubber base stent of the patient occlusion.

\section{RESULTS}

In this study 8 immediate custom made zirconium implants were implanted using tapping technique followed by measuring the primary stability using Periotest $\mathrm{M}$ to collect 2 readings for each patient. Patients were selected from outpatient clinic of Oral and Maxillofacial Surgery Department, Faculty of Dentistry, Cairo University. 
Demographic data of patients

\begin{tabular}{|c|c|c|c|c|c|}
\hline Patient No. & Gender & Age & Tooth & Periotest reading 1 & Periotest reading 2 \\
\hline 1 & Male & 19 & Upper right central & -3.5 & -3.8 \\
\hline 2 & Female & 47 & Upper right lateral & 6.6 & 6.5 \\
\hline 3 & Male & 35 & Upper left central & 7.6 & 7.8 \\
\hline 4 & Male & 39 & Upper left lateral & 5.9 & 6 \\
\hline 5 & Female & 35 & Upper right central & -1.1 & -1.2 \\
\hline 6 & Female & 21 & Upper left canine & -1.7 & -4 \\
\hline 7 & Female & 36 & Upper right $1^{\text {st }}$ premolar & -4.1 & -4.1 \\
\hline 8 & Female & 38 & Upper right $2^{\text {nd }}$ premolar & 8.3 & 8.3 \\
\hline
\end{tabular}

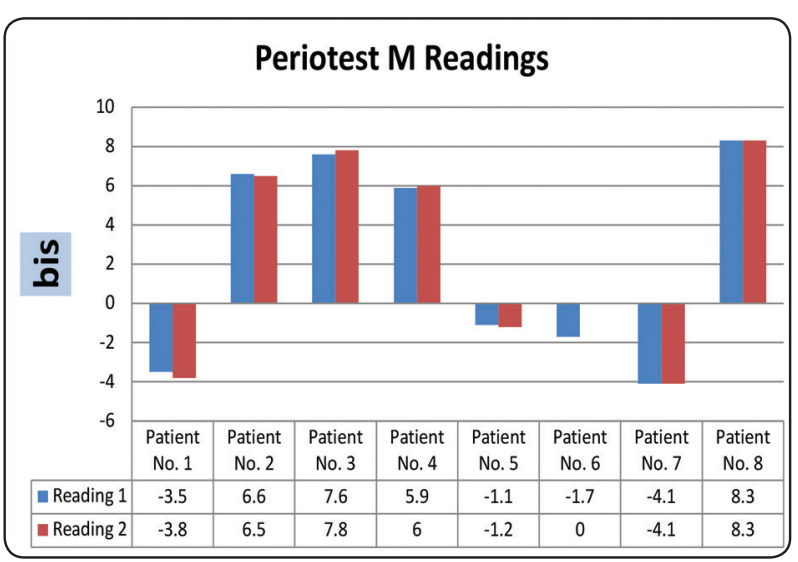

\begin{tabular}{|l|c|}
\hline Mean Value Reading 1 & 2.25 \\
\hline Mean Value Reading 2 & 2.4375 \\
\hline Total Mean Value & 2.34375 \\
\hline
\end{tabular}

The selected patients were 8 in number, with five females and three male patients. The gender distribution in the study was $63 \%$ female \& $38 \%$ male. The age of the selected group ranged from 19-47 years (average 33.75 years) \& a mean age of 35 years.

The teeth to be replaced were two upper right centrals; one upper left central, upper right lateral, upper left lateral, upper left canine, upper right 1st premolar and upper right 2nd premolar.

Interpretation of the patient's results, two readings were collected to measure and indicate the tooth mobility and assess the custom - made zirconium implant primary stability. There was a 10 to 20 minutes time difference between each reading, to allow for the return of the periodontium into its functional normal state.

Showing the number of days after-which the implant Failed Chart 5:

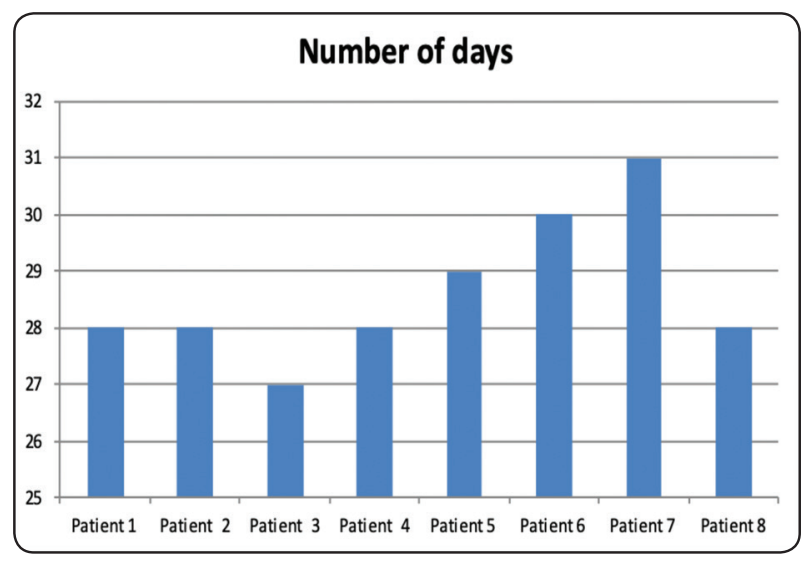

\begin{tabular}{|l|c|c|c|c|c|c|c|c|}
\hline & $\begin{array}{c}\text { Patient } \\
\text { No. } 1\end{array}$ & $\begin{array}{c}\text { Patient } \\
\text { No. } 2\end{array}$ & $\begin{array}{c}\text { Patient } \\
\text { No. } 3\end{array}$ & $\begin{array}{c}\text { Patient } \\
\text { No. } 4\end{array}$ & $\begin{array}{c}\text { Patient } \\
\text { No. } 5\end{array}$ & $\begin{array}{c}\text { Patient } \\
\text { No. } 6\end{array}$ & $\begin{array}{c}\text { Patient } \\
\text { No. } 7\end{array}$ & $\begin{array}{c}\text { Patient } \\
\text { No. } 8\end{array}$ \\
\hline Number of days & 28 & 28 & 27 & 28 & 29 & 30 & 31 & 28 \\
\hline
\end{tabular}




\section{DISCUSSION}

Pirker et al 2008 ${ }^{(9)}$ published a novel technique on a case and then followed it with a two year case report of using a zirconium custom made replica of an extracted tooth to substitute conventional titanium implants with success.

The idea of replicating the extracted tooth came to eliminate the need for the use of bone drills, which will induce bone necrosis; even the force applied while using the hand piece will increase the heat produced on bone according to Sunil Kumar et al $2014^{(10)}$.

In 1992, Lundgren et al ${ }^{(11)}$ experimented on animals, a model of an immediate titanium implant with very high success rate of $88 \%$. Implant success was described as a reliable fit between implant and bone bed. Then in 1997 Kohal RJ et al ${ }^{(12)}$, modified the approach to compensate for periodontal loss and concert a good unity between the implant and alveolar bone by widening the coronal aspect of the implant.

The emphasis on the importance of implant design and micro-topography on the implant success rate was immense. The term "de novo bone formation" was mentioned in 2011 by K. M. Regish et $\boldsymbol{a l}{ }^{(13)}$ to describe the additional bone ingrowth on the implant surface.

In 2010 W. Pirker et al ${ }^{(14)}$, stated that during a clinical trial all custom made zirconium implants failed to ossteointegrate despite being exposed to minimum loads during the first period after insertion although the implants were roughened and sandblasted. This result indicates that custom made zirconium implants replica of the tooth alone cannot provide the necessarily long term retention for osseointegration to occur. An identical replica of the tooth with perfect fit inside the extracted tooth socket will achieve a successful primary stability, but will be responsible for late term failure, because of the uniform pressure-induced resorption of the socket's alveolar surface, adding in a loose interlock between the implant and bone and failure of osseointegration. This induced pressure prevents the secondary stability of the custom made implant and leads to implant eventual failure.

In 2009 Kohal et al ${ }^{(15)}$ tried a different approach where the coronal aspect of the custom made zirconium implant is widened to compensate for the loss in periodontal tissue after extraction which is done to obtain congruence between the implant and the extraction socket. Unfortunately in several instances failure after implant insertion occurred due to fracture of the thin labial wall of the alveolar ridge.

D shruthi et al $2011^{(16)}$ proved in his discussion that the immediate placement of custom made zirconium implants tapping technique is very case sensitive since it depends a lot on the periodontal state of the extracted tooth which should be sound with sufficient deep socket to provide a reasonable bone support; also the extraction process should be completely atraumatic and absence of any periapical pathologies.

Periotest has limited clinical use since it cannot measure the mesio-distal mobility and the position and angle of the rod affects the measured value. Also, it cannot detect the small changes in the implant- bone surface. The most failing point of this method is that the percussing force on the implant may deteriorate the stability in poor initial stability implants ${ }^{(17)}$.

Quentin Flamant et al $2016^{(18)}$ showed that the rougher the implant surface, the better is the osseointegration. Also a study by Sammons et al $2005^{(19)}$, have shown that surface roughness influences a number of events in the behavior of cells in the osteoblastic lineage, including spreading and proliferation, differentiation, and protein synthesis so the effect of surface roughness extends on a cellular level. 
Yet this trial was greatly influenced by the technique introduced by Pirker et al $2008^{(20)}$, the outcome shown in this research failed to prove any success. All the implants failed to osseointegrate after 3 weeks of implantation. Therefore the secondary outcome couldn't be accomplished.

\section{CONCLUSION \& RECOMMENDATIONS}

The aim of the present study was to evaluate the primary stability of immediate, custom made zirconium root analogue implant after 3 month of implantation. 8 custom made zirconium dental implants were tailored specifically for 8 different patients; after being scanned using a laser scanner to produce a replica of the tooth. The described technology used in this study is a combination of true anatomical implant replica of the patient's unrestorable tooth and the use of a novel biomaterialzirconium after being modified by adding blebs for added retention using CAD-CAM software and finally milled and sand blasted and sterilized before implantation. The study was minimally invasive with respect to underlying anatomy; it is also time and cost effective with improved esthetic results.

Within the limitations of this study the authors could neither measure the stability nor the marginal bone changes due to the failure of the custom made zirconium implants to osseointegrate. Despite following Pirker et al ${ }^{(21)}$ protocol, all the eight implants failed to osseointegrat after 3 weeks with a mean number of days 28.625 .

- There should be manufacturing facilities that are equipped with much advanced technology in decontaminating, and sterilizing the custom made dental implant; also better facilities to prepare the dental implant with double acid etching, sandblasting and sintering. The authors of this study forecast that if hydrofluoric acid etching was used it might have given a better outcome.

- Further changes in the design of the dental implant in the macro-retentive features should be addressed; changing the dimension and shape of the blebs.

- The design could have been altered to accommodate the smartpeg to allow the use of the Ostell device.

- For future study conducted on custom made zirconium dental implants, the authors recommend having a larger sample size in order to have a variety of patients with different bone densities.

\section{REFERENCES}

1. Rajput, Rajan, Zakariya Chouhan, Monica Sindhu, Sowmya Sundararajan, and Ravi Raj Singh Chouhan. "A Brief Chronological Review of Dental Implant History." International Dental Journal of Students Research 4 (2016).

2. Nader Elbokle, Aisha Khaled and Mohammed Ashraf. "Asesment of primary stability of immediate two piece zirconium implants placed in fresh sockets in esthetic zone (Quasi experimental design)" Egyptian Dental Journal 2019.

3. Hodosh M, Povar M, shklar G.The dental Polymer implant concept. J Prosthet Dent 1969 and 22:371-380. .

4. Santos, M. C. L. G., M. I. G. Campos, and S. R. P. Line. "Early dental implant failure: A review of the literature." Braz J Oral Sci 1, no. 3 (2002): 103-11 .

5. Pelegrine, André Antonio, Carlos Eduardo Sorgi Da Costa, Maria Elvira Pizzigatti Correa, and José Francisco Comenalli Marques Jr. "Clinical and histomorphometric evaluation of extraction sockets treated with an autologous bone marrow graft.” Clinical Ora.

6. Saini, Monika, Yashpal Singh, Pooja Arora, Vipin Arora, and Krati Jain. "Implant biomaterials: A comprehensive review." World Journal of Clinical Cases: WJCC 3, no. 1 (2015): 52 . .

7. Mendonça, Gustavo, Daniela BS Mendonça, Francisco JL Aragao, and Lyndon F. Cooper. "Advancing dental implant surface technologyf-rom micron-to nanotopography." Biomaterials 29, no. 28 (2008): 3822-3835.

8. Ebenezer, Vijay, K. Balakrishnan, R. Vigil Dev Asir, and Banu Sragunar. "Immediate placement of endosseous implants into the extraction sockets." Journal of pharmacy \& bioallied sciences 7, no. Suppl 1 (2015): S234. 
9. Pirker, W., and A. Kocher. "Immediate, non-submerged, root-analogue zirconia implant in single tooth replacement." International journal of oral and maxillofacial surgery 37, no. 3 (2008): 293-295.

10. Mishra, Sunil Kumar, and Ramesh Chowdhary. "Heat generated by dental implant drills during osteotomy-a review." The Journal of Indian Prosthodontic Society 14, no. 2 (2014): 131-143.

11. Lundgren, D., H. Rylander, M. Anderssong, C. Johansson, and T. Albrektsson. "Healing-in of root analogue titanium implants placed in extraction sockets. An experimental study in the beagle dog." Clinical oral implants research 3, no. 3 (1992): 136-144.

12. Kohal, Ralf-J., Markus B. Hürzeler, Luis F. Mota, Gerold Klaus, Raul G. Caffesse, and Jörg R. Strub. "Custom-made root analogue titanium implants placed into extraction sockets. An experimental study in monkeys." Clinical Oral Implants Research 8, no. 5.

13. Prithviraj, D. R., K. M. Regish, Sharma Deeksha, and D. Shruthi. "Extraction and immediate placement of root analogue zirconia implants: an overview." (2011). .

14. Pirker, W., D. Wiedemann, A. Lidauer, and A. A. Kocher. "Immediate, single stage, truly anatomic zirconia implant in lower molar replacement: a case report with 2.5 years follow-up." International journal of oral and maxillofacial surgery 40, no. 2 (2011).

15. Kohal, Ralf-Joachim, Marko Knauf, Birgitta Larsson, Herman Sahlin, and Frank Butz. "One-piece zirconia oral implants: one-year results from a prospective cohort study. Single tooth replacement." Journal of clinical periodontology 39, no. 6 (2012): 590.

16. Prithviraj, D. R., K. M. Regish, Sharma Deeksha, and D. Shruthi. "Extraction and immediate placement of root analogue zirconia implants: an overview." (2011). .

17. Satwalekar, Parth, Sandeep Nalla, Ramaswamy Reddy, and Sheeba Glory Chowdary. "Clinical evaluation of osseointegration using resonance frequency analysis." The Journal of the Indian Prosthodontic Society 15, no. 3 (2015): 192.

18. Flamant, Quentin, Fernando García Marro, Joan Josep Roa Rovira, and Marc Anglada. "Hydrofluoric Acid Etching of Dental Zirconia. Part 1: Etching Mechanism and Surface
Characterization." Journal of the European Ceramic Society 36, no. 1 (2016): 121-134. .

19. Sammons, Rachel L., Narong Lumbikanonda, Michael Gross, and Philip Cantzler. "Comparison of osteoblast spreading on microstructured dental implant surfaces and cell behaviour in an explant model of osseointegration: a scanning electron microscopic study.".

20. Pirker, W., and A. Kocher. "Immediate, non-submerged, root-analogue zirconia implants placed into single-rooted extraction sockets: 2-year follow-up of a clinical study." International journal of oral and maxillofacial surgery 38 , no. 11 (2009): 1127-1132.

21. Pirker, W., and A. Kocher. "Immediate, non-submerged, root-analogue zirconia implant in single tooth replacement." International journal of oral and maxillofacial surgery 37 , no. 3 (2008): 293-295. .

22. Rajput, Rajan, Zakariya Chouhan, Monica Sindhu, Sowmya Sundararajan, and Ravi Raj Singh Chouhan. "A Brief Chronological Review of Dental Implant History.” International Dental Journal of Students Research 4 (2016).

23. Hodosh M, Povar M, shklar G.The dental Polymer implant concept. J Prosthet Dent 1969 and 22:371-380.

24. Santos, M. C. L. G., M. I. G. Campos, and S. R. P. Line. "Early dental implant failure: A review of the literature." Braz J Oral Sci 1, no. 3 (2002): 103-11.

25. Saini, Monika, Yashpal Singh, Pooja Arora, Vipin Arora, and Krati Jain. "Implant biomaterials: A comprehensive review." World Journal of Clinical Cases: WJCC 3, no. 1 (2015): 52.

26. Ebenezer, Vijay, K. Balakrishnan, R. Vigil Dev Asir, and Banu Sragunar. "Immediate placement of endosseous implants into the extraction sockets." Journal of pharmacy \& bioallied sciences 7, no. Suppl 1 (2015): S234.

27. Mendonça, Gustavo, Daniela BS Mendonça, Francisco JL Aragao, and Lyndon F. Cooper. "Advancing dental implant surface technology-from micron-to nanotopography." Biomaterials 29, no. 28 (2008): 3822-3835.

28. Pelegrine, André Antonio, Carlos Eduardo Sorgi Da Costa, Maria Elvira Pizzigatti Correa, and José Francisco Comenalli Marques Jr. "Clinical and histomorphometric evaluation of extraction sockets treated with an autologous bone marrow graft." Clinical Oral. 